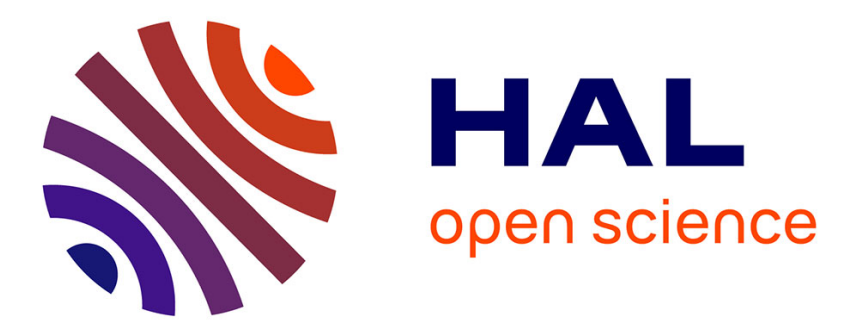

\title{
Direct electrochemical reduction of solid uranium oxide in molten fluoride salts
}

Mathieu Gibilaro, Laurent Cassayre, Olivier Lemoine, Laurent Massot, Olivier Dugne, Rikard Malmbeck, Pierre Chamelot

\section{- To cite this version:}

Mathieu Gibilaro, Laurent Cassayre, Olivier Lemoine, Laurent Massot, Olivier Dugne, et al.. Direct electrochemical reduction of solid uranium oxide in molten fluoride salts. Journal of Nuclear Materials, 2011, vol. 414, pp. 169-173. 10.1016/j.jnucmat.2011.02.053 . hal-00815297

\section{HAL Id: hal-00815297 \\ https://hal.science/hal-00815297}

Submitted on 18 Apr 2013

HAL is a multi-disciplinary open access archive for the deposit and dissemination of scientific research documents, whether they are published or not. The documents may come from teaching and research institutions in France or abroad, or from public or private research centers.
L'archive ouverte pluridisciplinaire HAL, est destinée au dépôt et à la diffusion de documents scientifiques de niveau recherche, publiés ou non, émanant des établissements d'enseignement et de recherche français ou étrangers, des laboratoires publics ou privés. 


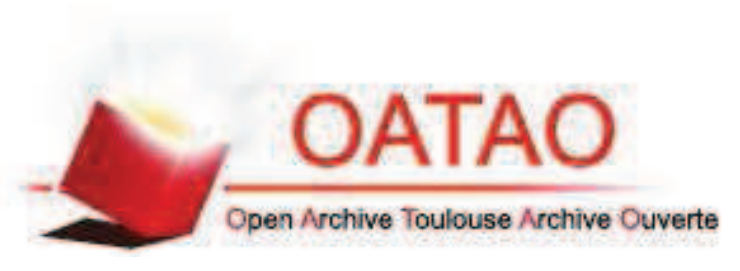

\section{Open Archive Toulouse Archive Ouverte (OATAO)}

OATAO is an open access repository that collects the work of Toulouse researchers and makes it freely available over the web where possible.

This is an author-deposited version published in: http://oatao.univ-toulouse.fr/ Eprints ID: 8615

To link to this article: DOI: $10.1016 /$ j.jnucmat.2011.02.053

URL: http://dx.doi.org/10.1016/j.jnucmat.2011.02.053

To cite this version: Gibilaro, Mathieu and Cassayre, Laurent and Lemoine, Olivier and Massot, Laurent and Dugne, Olivier and Malmbeck, Rikard and Chamelot, Pierre Direct electrochemical reduction of solid uranium oxide in molten fluoride salts. (2011) Journal of Nuclear Materials, vol. 414 (n 2). pp. 169-173. ISSN 0022-3115

Any correspondence concerning this service should be sent to the repository administrator: staff-oatao@listes-diff.inp-toulouse.fr 


\title{
Direct electrochemical reduction of solid uranium oxide in molten fluoride salts
}

\author{
Mathieu Gibilaro ${ }^{\mathrm{a}, *}$, Laurent Cassayre $^{\mathrm{a}}$, Olivier Lemoine ${ }^{\mathrm{a}}$, Laurent Massot ${ }^{\mathrm{a}}$, Olivier Dugne ${ }^{\mathrm{b}}$, \\ Rikard Malmbeck $^{\mathrm{c}}$, Pierre Chamelot ${ }^{\mathrm{a}}$ \\ ${ }^{a}$ Laboratoire de Génie Chimique UMR 5503, Département Procédés Electrochimiques, Université de Toulouse, 31062 Toulouse Cedex, France \\ ${ }^{\mathrm{b}}$ CEA Marcoule-DEN/DTEC/SGCS, Laboratoire de Métallographie et d'Analyse Chimique, BP17171, 30207 Bagnols Sur Cèze Cedex, France \\ ${ }^{\mathrm{C}}$ Institute for Transuranium Elements, Joint Research Centre, P.O. Box 2340, 76125 Karlsruhe, Germany
}

\section{Introduction}

Advanced nuclear fuel cycles are under development worldwide in order to minimise the amount of high radiotoxic waste generated by nuclear power plants operation. New technologies have to be economically competitive, environmentally safe and resistant to proliferation. Within most of the developed future fuel cycles, recycling of actinides $(\mathrm{Cm}, \mathrm{Pu}, \mathrm{Am}, \mathrm{Np})$ from spent nuclear fuel is required due to their significant impact on its radiotoxicity and pyrochemical methods represent one of the promising options to fulfil this task.

Several options are based on an electrorefining stage for the pyrochemical treatment of nuclear spent fuel. In the process being developed in the ITU/JRC [1], all actinides are group-selectively recovered in a form of actinide-aluminium ( $\mathrm{An}-\mathrm{Al}$ ) alloys by an electrorefining process in molten $\mathrm{LiCl}-\mathrm{KCl}$ using solid aluminium cathodes. In Japan, pyrometallurgical processing technology for spent metallic fuel is studied in $\mathrm{LiCl}-\mathrm{KCl}$ where $\mathrm{U}$ and $\mathrm{Pu}$ are recovered on a liquid $\mathrm{Cd}$ cathode, leaving the fission products in the salt [2]. Parallel developments in Argonne National Laboratory (US) and in Korea aim at an actinide-fission products separation by elect-

\footnotetext{
* Corresponding author.

E-mail address: gibilaro@chimie.ups-tlse.fr (M. Gibilaro).
}

rorefining onto first a solid cathode to recover the $U$ and then onto a liquid Cd cathode for the transuranium elements recovery [3,4].

All these pyrochemical separation processes by electrorefining have in common a starting material made of metallic fuel. Indeed, oxide fuels are not suitable for the electrorefining process, since these ceramics are mostly insoluble in molten salts. Therefore, a preliminary step is required to convert oxide into metal which can be easily dissolved in molten salts by anodic dissolution.

The lithium reduction process has been developed for the pyrochemical recycling of oxide fuels using lithium metal as a reductant to convert actinide oxides into metal. For instance, Usami et al. [5] successfully applied this technique to $\mathrm{AmO}_{2}$ in $\mathrm{LiCl}-\mathrm{Li}_{2} \mathrm{O}$ at $650^{\circ} \mathrm{C}$ and have shown that more than $99.9 \%$ of Am was recovered into a solid Am phase. This technology was also employed for $\mathrm{UO}_{2}$ and $\mathrm{PuO}_{2}$ with $3 \%$ of Am at $650{ }^{\circ} \mathrm{C}$ [6] leaving particles of $\mathrm{UO}_{2}$ totally reduced. For Pu samples, small amounts of $\mathrm{Pu}$ and Am were detected in the salts. Moreover, $\mathrm{AmO}_{2}$ reduction was only efficient for low $\mathrm{Li}_{2} \mathrm{O}$ concentration $\left(<1.6\right.$ mass.\% $\mathrm{Li}_{2} \mathrm{O}$ ). Thus an additional step is needed to control and decrease $\mathrm{Li}_{2} \mathrm{O}$ concentration as it accumulates in the salt during the process.

To avoid these problems, a more efficient process has been elaborated based on a direct electrochemical reduction of oxide. This pyroprocess has been developed by Chen et al. [7], who first demonstrated the direct electroreduction of $\mathrm{TiO}_{2}$ into $\mathrm{Ti}$ at $950{ }^{\circ} \mathrm{C}$ in molten $\mathrm{CaCl}_{2}$. This innovative method is called the FFC Cambridge process (Fray-Farthing-Chen). The overall reaction is on one side 
the electroreduction of a solid oxide, $\mathrm{MO}_{2}$, into metal, $\mathrm{M}$, at the cathode (Eq. (1)) and on the other side the evolution of $\mathrm{CO}$ and $\mathrm{CO}_{2}$ at the anode (Eq. (2) and (3)). The oxide ions released at the cathode are transported through the support electrolyte and oxidised at a carbon anode:

$\mathrm{MO}_{2}(\mathrm{~s})+4 \mathrm{e}^{-}=\mathrm{M}(\mathrm{s}, \mathrm{l})+2 \mathrm{O}^{2-}($ salt $)$

$\mathrm{O}^{2-}($ salt $)+\mathrm{C}(\mathrm{s})=\mathrm{CO}(\mathrm{g})+2 \mathrm{e}^{-}$

$2 \mathrm{O}^{2-}$ (salt $)+\mathrm{C}(\mathrm{s})=\mathrm{CO}_{2}(\mathrm{~g})+4 \mathrm{e}^{-}$

As $\mathrm{O}^{2-}$ ions produced at the cathode are simultaneously consumed at the anode, the oxide ions concentration remains constant in the molten salt, preventing accumulation during the experiment. Moreover, the troublesome handling of Li metal (which is highly reactive with water and oxygen) encountered in the lithium reduction process is avoided.

On top of multiple applications to the preparation of various metals ( $\mathrm{Ti}$ [8], Nb [9], Si [10]...), the FFC process is also studied in the framework of nuclear spent fuel reprocessing. The electroreduction of $\mathrm{UO}_{2}$ and $\mathrm{MOX}\left(\mathrm{UO}_{2}-\mathrm{PuO}_{2}\right)$ have been studied in molten $\mathrm{LiCl}$ and $\mathrm{CaCl}_{2}$ solvents [11-13].

However, one of the major troubles with the FFC process is the use of a reactive carbon anode where $\mathrm{CO}_{2}$ gas is released. The final product often contains carbides, due to the reduction of carbonates $\mathrm{CO}_{3}^{2-}$, formed by the reaction of the $\mathrm{CO}_{2}(\mathrm{~g})$ with $\mathrm{O}^{2-}$ dissolved in the salt [14-16].

An inert Pt anode is sometimes used, but Pt dissolution into $\mathrm{Pt}(\mathrm{II})$ ions at low $\mathrm{O}^{2-}$ content or its corrosion at higher oxide concentration, through $\mathrm{Li}_{2} \mathrm{PtO}_{3}$ formation, has been reported by several authors [12,17].

In this work, a different category of electrolyte was tested, i.e. the molten fluorides, with the advantage of using an inert gold anode on which oxygen ions are oxidised into $\mathrm{O}_{2}[18,19]$ :

$2 \mathrm{O}^{2-}=\mathrm{O}_{2}(\mathrm{~g})+4 \mathrm{e}^{-}$

This anodic reaction prevents the carbides formation at the cathode and the corrosion of the anode material.

The first part of the work was focused on the electrochemical characterisation of the $\mathrm{UO}_{2}$ samples in fluoride salts by linear sweep voltammetry. Galvanostatic electrolyses have been performed on single pellets of about 200-300 $\mathrm{mg}$ and the reaction products have been characterised by SEM-EDX, EPMA/WDS, microhardness and XRD.

\section{Experimental}

The cell used consisted of a vitreous carbon crucible placed in a cylindrical vessel made of refractory steel (SS 310L). The inner part of the walls was protected against fluoride vapours by a graphite liner. Experiments were performed under an inert argon (U grade) atmosphere. The experimental set-up is described in detail in a previous paper [20].

The electrolyte $(200 \mathrm{~g})$ consisted of the eutectic $\mathrm{LiF}-\mathrm{CaF}_{2}$ (SDS $99.99 \%)$ dehydrated by heating under vacuum $\left(3 \times 10^{-2}\right.$ bar) from room temperature up to the melting point for $72 \mathrm{~h}$. Lithium oxide $\left(\mathrm{Li}_{2} \mathrm{O}\right.$ ) powder (Cerac 99.5\%) was used to provide oxide ions into the bath.

$\mathrm{UO}_{2}$ was used in the form of sintered pellets (densification 95\%). The oxide pellets, attached with a molybdenum mesh and connected to the current lead by a molybdenum wire, were used as working electrodes. The auxiliary electrode was a gold spiral with a large surface area $\left(S=3.6 \mathrm{~cm}^{2}\right)$ and all potentials were referred to a platinum wire $(0.5 \mathrm{~mm}$ diameter $)$, acting as a quasi-reference electrode $\mathrm{Pt} / \mathrm{PtO}_{x} / \mathrm{O}^{2-}$ [21]. Although this electrode is sensitive to oxide concentration in the bath, its potential remains stable for high oxide concentration ( $>1 \mathrm{wt} \%$ ).

The electrochemical experiments were performed with an Autolab PGSTAT 30 potentiostat/galvanostat. After resin embedding and polishing, the cathode bulk was examined with a Scanning Electron Microscope (ZEISS Supra55) equipped with an EDX probe (Oxford SDD X-Max), X-ray Diffraction (Bruker D8) and Electron Probe Micro Analysis combined with Wavelength Dispersive Spectrometer (CAMECA SX 100). Microhardness was used to identify $\mathrm{UO}_{2}$ or metallic uranium (Schimadzu HMV-2000).

\section{Results and discussion}

\subsection{Solvent selection}

In order to perform the direct reduction of the uranium oxide, the solvent selection is primordial as the uranium formation must occur at a potential more positive than that of the alkaline deposition. The Gibbs energy of the reaction $\left(\Delta_{r} G^{\circ}\right)$ between the metallic oxide $\mathrm{UO}_{2}$ and the alkaline metal ( $\mathrm{Ca}, \mathrm{Na}$ or $\mathrm{Li}$ ), according to Eq. (5), provides a good indication on the reduction potential of the oxide:

$\mathrm{UO}_{2}+$ Alkaline $(\mathrm{Ca}, \mathrm{Li}, \mathrm{Na})=\mathrm{U}+$ Alkaline oxide

If $\Delta_{r} G^{\circ}$ of the reaction is negative, the reduction of the oxide occurs at a potential more positive than the solvent alkaline deposition and the direct reduction is then achievable from a thermodynamical point of view. Calculations have been performed using compiled thermodynamic data [22]. When the alkaline is $\mathrm{Li}$, the Gibbs energy of reaction (5) is negative: $\Delta_{r} G^{\circ}\left(750^{\circ} \mathrm{C}\right)=-17,382$ $\mathrm{J} \mathrm{mol}^{-1}$ and $\Delta_{r} G^{\circ}\left(850{ }^{\circ} \mathrm{C}\right)=-6,682 \mathrm{~J} \mathrm{~mol}^{-1}$. Conversely, when the alkaline is $\mathrm{Na}$, the Gibbs energy of reaction (5) is strongly positive: $\Delta_{r} G^{\circ}\left(750{ }^{\circ} \mathrm{C}\right)=354,079 \mathrm{~J} \mathrm{~mol}^{-1}$ and $\Delta_{r} G^{\circ}\left(850^{\circ} \mathrm{C}\right)=363864 \mathrm{~J} \mathrm{~mol}^{-1}$.

According to these thermochemical considerations, the direct electroreduction of $\mathrm{UO}_{2}$ has been investigated in the eutectic $\mathrm{LiF}-\mathrm{CaF}_{2}$ at $850^{\circ} \mathrm{C}$. Oxide ions were introduced in the bath using $\mathrm{Li}_{2} \mathrm{O}$ additions at a concentration of $2 \mathrm{wt} \%$, which is lower than its solubility limit in $\mathrm{LiF}-\mathrm{CaF}_{2}[23]$.

\subsection{Influence of oxide ions}

\subsubsection{Cathode reactions}

Fig. 1 presents linear sweep voltammograms at $10 \mathrm{mV} / \mathrm{s}$ on a Mo wire and on a Mo mesh performed in $\mathrm{LiF}-\mathrm{CaF}_{2}$ with and without oxide ions. In the linear voltammograms plotted in the pure fluoride salt on Mo wire without $\mathrm{Li}_{2} \mathrm{O}$ addition (black curve), no

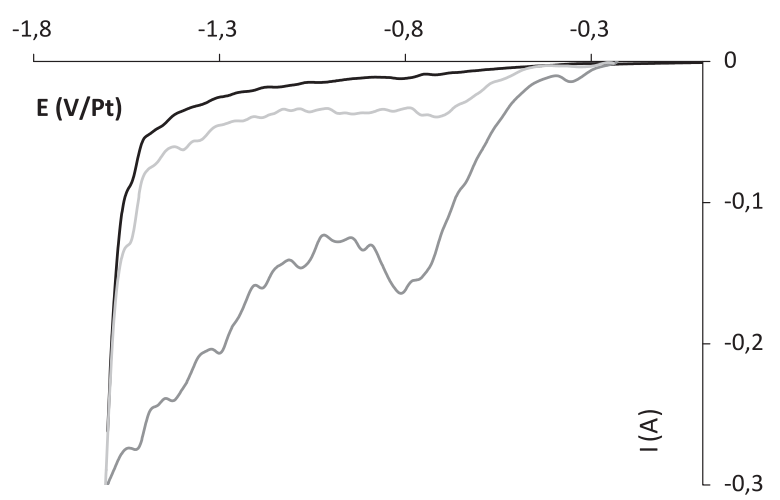

Fig. 1. Linear sweep voltammograms on $\mathrm{Mo}$ in $\mathrm{LiF}-\mathrm{CaF}_{2}$ at $10 \mathrm{mV} / \mathrm{s}$; black: Mo wire without $\mathrm{Li}_{2} \mathrm{O}$, light grey: Mo wire with 2 mass.\% $\mathrm{Li}_{2} \mathrm{O}$, dark grey: Mo mesh with 2 mass.\% $\mathrm{Li}_{2} \mathrm{O}$. 
reduction current is observed between 0 and $-1.5 \mathrm{~V} / \mathrm{Pt}$, and metallic lithium deposition occurs at $-1.6 \mathrm{~V} / \mathrm{Pt}$. In $\mathrm{Li}_{2} \mathrm{O}$ containing solvent, an additional current is observed at around $-0.8 \mathrm{~V} / \mathrm{Pt}$, both on Mo wire (light grey) and mesh (dark grey). As presented in Fig. 1, the recorded current increases with increasing Mo surface. Experimental observations show that this additional current is observed on fresh Mo electrodes in presence of $\mathrm{Li}_{2} \mathrm{O}$; however, no spontaneous reaction has been yet categorically identified. In order to clean the surface of fresh Mo electrodes, linear sweep voltammetries in the cathodic side have been systematically performed until the complete disappearance of the cathodic current.

\subsubsection{Anode reactions}

The expected anodic reactions on a gold electrode in fluoride media in the presence of oxide ions are either the anodic dissolution of gold or the oxygen gas formation. To avoid the consumption of the $\mathrm{Au}$ electrode, the $\mathrm{Li}_{2} \mathrm{O}$ concentration in the melt has to be controlled and maintained to a sufficient level. Linear sweep voltammetries plotted on $\mathrm{Au}$ at $10 \mathrm{mV} / \mathrm{s}$ for two different concentrations of oxide ions are presented in Fig. 2.

At low oxide concentrations ( 0.5 mass.\% $\left.\mathrm{Li}_{2} \mathrm{O}\right)$, a current plateau caused by the diffusion limitation of $\mathrm{O}^{2-}$ ions is observed at around $2.8 \mathrm{~V} / \mathrm{Pt}$, with an intensity of $150 \mathrm{~mA}$. At potentials higher than $3.3 \mathrm{~V}$, the Au electrode is oxidised. An increase of oxide concentration ( 2 mass.\% $\mathrm{Li}_{2} \mathrm{O}$ ) allows a much higher current density $\left(>0.7 \mathrm{~A} / \mathrm{cm}^{2}\right)$ for the $\mathrm{O}_{2}$ evolution reaction to be reached, thus preventing the anodic dissolution of the gold electrode. Based on these results, attention was paid to work in $\mathrm{LiF}-\mathrm{CaF}_{2}$ with 2 mass.\% $\mathrm{Li}_{2} \mathrm{O}$.

\subsection{Electrochemical reduction of uranium oxide pellets}

3.3.1. Electrochemical characterisation by linear sweep voltammetry

Fig. 3 shows the linear voltammetries obtained at $10 \mathrm{mV} / \mathrm{s}$ on $\mathrm{UO}_{2}$ sample. It can be noticed that a lower OCP value is measured on $\mathrm{UO}_{2}$ in Mo mesh than on Mo alone. Indeed, to obtain a clean Mo surface, a few linear voltammetries were plotted as explained in Section 3.2.1. Meanwhile, the reduction of $\mathrm{UO}_{2}$ most probably started, explaining why the OCP value decreased: instead of having a potential imposed by a Mo couple, the rest potential is then driven by a $U$ redox system.

As shown in Fig. 3, an additional reduction current peak is observed before the solvent deposition at around $-1.45 \mathrm{~V} / \mathrm{Pt}$ and is attributed to the direct electrochemical reduction of $\mathrm{UO}_{2}$ in fluoride salts, which is in good adequation with the previous thermodynamic analysis.

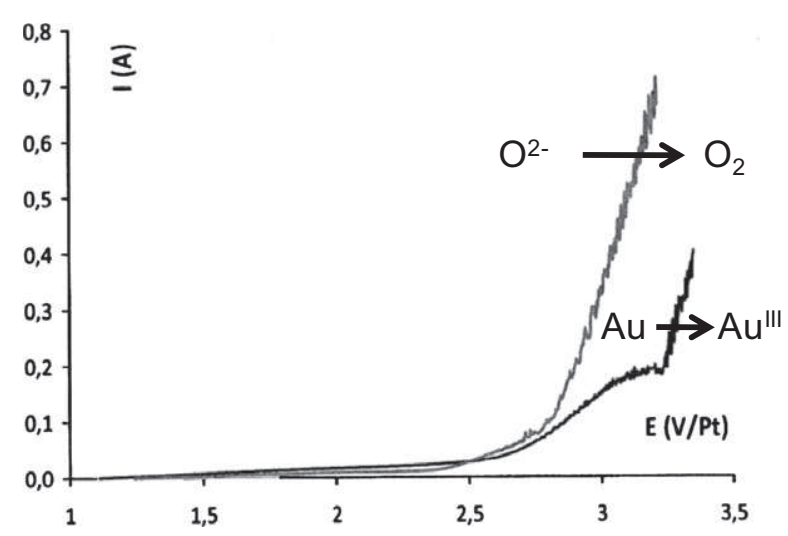

Fig. 2. Linear sweep voltammograms on $\mathrm{Au}$ electrode in $\mathrm{LiF}-\mathrm{CaF}_{2}$ at $10 \mathrm{mV} / \mathrm{s}$ at $850{ }^{\circ} \mathrm{C}$; the black curve is plotted for 0.5 mass.\% $\mathrm{Li}_{2} \mathrm{O}$ and the grey curve for 2 mass.\% $\mathrm{Li}_{2} \mathrm{O}$.

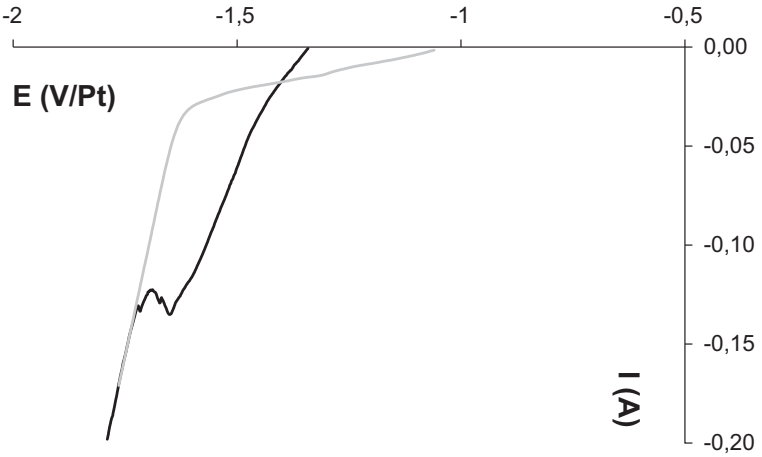

Fig. 3. Linear sweep voltammograms (after Mo cleaning) in $\mathrm{LiF}-\mathrm{CaF}_{2}-\mathrm{Li}_{2} \mathrm{O}$ $\left(2\right.$ mass.\% $\mathrm{Li}_{2} \mathrm{O}$ ) at $10 \mathrm{mV} / \mathrm{s}$ and $850{ }^{\circ} \mathrm{C}$; the black curve is plotted on $\mathrm{UO}_{2}$ sample and the grey curve is the solvent reduction on Mo mesh.

\subsubsection{Galvanostatic electrolysis of uranium oxide}

Direct reduction experiments have been conducted in constantcurrent mode, for different intensity and duration. One of the reason of not using a constant-potential mode is that, during the electrolyses, the oxide pellets were gradually reduced into metal, leading to a significant increase of their electronic conductivity and thus a decrease of the ohmic drop in the circuit. Moreover, no stable reference electrode is currently available in fluoride salts, inhibiting the possibility of an accurate control of the cathodic potential during the course of the electrolyses.

Five reduction tests were carried out in $\mathrm{LiF}-\mathrm{CaF}_{2}$ containing 2 mass.\% $\mathrm{Li}_{2} \mathrm{O}$ at $850{ }^{\circ} \mathrm{C}$; the applied cathodic current was increased between each test. The results concerning the two most interesting runs are presented in this section. The first noticeable $\mathrm{UO}_{2}$ reduction experiment was performed during $8000 \mathrm{~s}$ at $-150 \mathrm{~mA}$, this current value being lower than the maximum current observed to avoid metallic lithium deposition. These conditions correspond to $200 \%$ of the coulombs theoretically calculated from the oxide pellet initial weight. The cross section was observed by SEM and is presented in Fig. 4.

Three different zones are clearly observed. The internal zone (1) corresponds to the bulk part of the initial material; it has a typical microhardness of $684 \mathrm{HV}$, close to $640 \mathrm{HV}$ for $\mathrm{UO}_{2}$ [24], meaning that the sample is not fully reduced. A focus on zones (2) and (3) is shown in Fig. 5. Compared to the initial material, the intermediate zone (2) surface is cracked. At the grain boundaries, fluoride salts are detected by SEM-EDX. Shiny metallic particles are also observed and EPMA-WDS analysis indicated that they are made of $U$ metal. Thus, the initial stage of reduction is observed at the grain

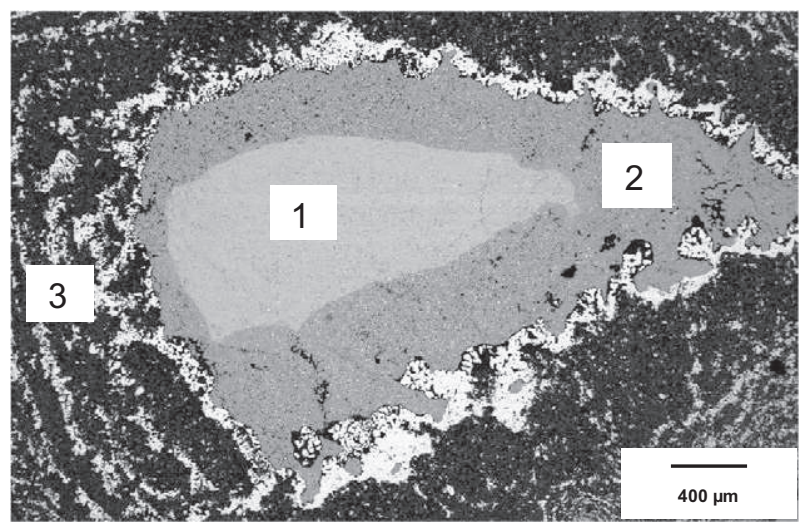

Fig. 4. SEM observation of $\mathrm{UO}_{2}$ pellet cross section after electrolysis $(I=-0.15 \mathrm{~A}$ and $t=8000 \mathrm{~s})$ at $850{ }^{\circ} \mathrm{C}$ in $\mathrm{LiF}-\mathrm{CaF}_{2}-\mathrm{Li}_{2} \mathrm{O}\left(2\right.$ mass.\% $\left.\mathrm{Li}_{2} \mathrm{O}\right)$. 

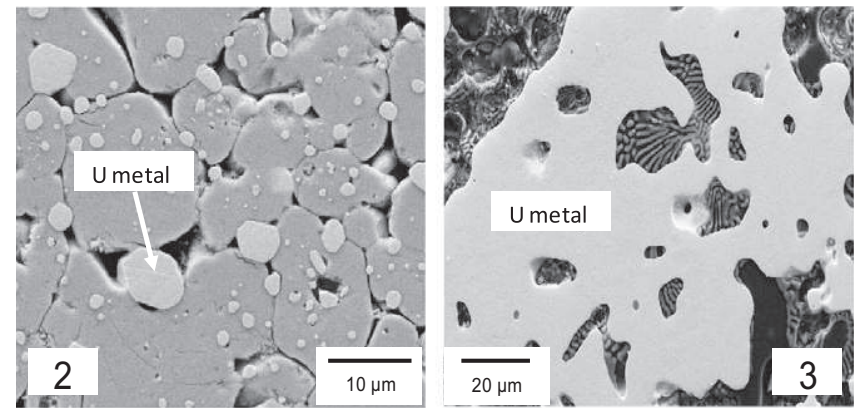

Fig. 5. Focus on zones (2) and (3) observed by SEM of $\mathrm{UO}_{2}$ pellet after electrolysis $(I=-0.15 \mathrm{~A}$ and $t=8000 \mathrm{~s})$ at $850{ }^{\circ} \mathrm{C}$ in $\mathrm{LiF}-\mathrm{CaF}_{2}-\mathrm{Li}_{2} \mathrm{O}\left(2\right.$ mass.\% $\left.\mathrm{Li}_{2} \mathrm{O}\right)$.

boundary in this partially reduced region with uranium metallic grains. Kurata et al. [11] have already observed that the grain boundary is reduced prior to the bulk due to a better diffusion along itself.

The external layer of the pellet (3) has a typical coral-like structure due to oxygen removal. It is composed of uranium metal as proved in EDX analysis and microhardness measurements (282 HV compared to 280-289 HV for metallic uranium [25]). These observations show that the direct reduction took place progressively in the pellet starting from the outside.

Progression of the oxide pellet reduction is presented in Fig. 6 where three zones are observed as previously: $1-\mathrm{UO}_{2}, 2-\mathrm{UO}_{2-x}$, 3-U metal. The reduction mechanism is then the following: as metal is being produced, it extends the point of contact to further oxide grains, which can be successively reduced. This test demonstrates that $U$ was obtained with uranium oxide as starting material.

Another run realised with a higher current $(I=-0.3$ A during $7200 \mathrm{~s}$ ) allowed to prove that the full reduction of $\mathrm{UO}_{2}$ is achievable in fluoride salts. The polished cross section is presented in Fig. 7.

On the left part of the picture, the product after electrolysis has a very porous surface, specific of the direct electrochemical reduction, suggesting that the pellet is completely reduced. On the right part is shown the 3D structure: uranium metal forms a continuous network where gaps are formed by oxygen removal and uranium rearrangement.

XRD analysis of the final product reveals the presence of the following phases: uranium metal, uranium dioxide, uranium oxide hydrate, lithium fluoride, calcium fluoride and calcium oxide. Lithium and calcium compounds come from the solvent while uranium oxide and hydrate might be formed by spontaneous native oxidation of uranium metal due to air exposure [26]. The thickness of this oxide layer was evaluated to be around $30 \mathrm{~nm}$ by EPMAWDS, using the specific software X-Film. After polishing the sample and thus removing the surface oxide layer, another XRD measurement was performed. The spectrum is presented in Fig. 8

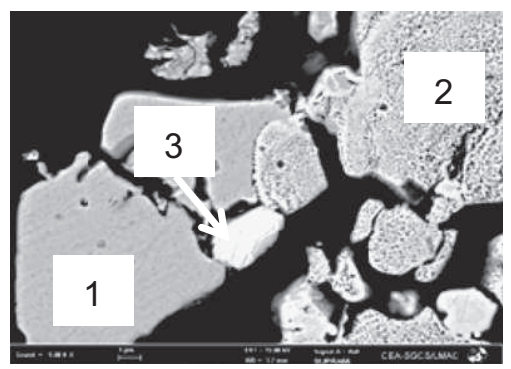

Fig. 6. $\mathrm{UO}_{2}$ reduction mechanism observed by SEM on a pellet cross section after electrolysis $(I=-0.15 \mathrm{~A}$ and $t=8000 \mathrm{~s})$ at $850{ }^{\circ} \mathrm{C}$ in $\mathrm{LiF}-\mathrm{CaF}_{2}-\mathrm{Li}_{2} \mathrm{O}\left(2\right.$ mass.\% $\left.\mathrm{Li}_{2} \mathrm{O}\right)$.

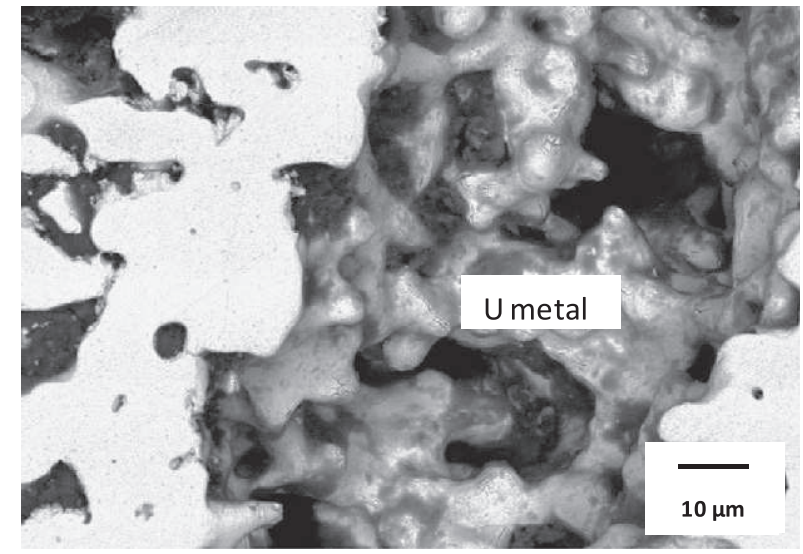

Fig. 7. SEM observation of $\mathrm{UO}_{2}$ pellet cross section after electrolysis $(I=-0.3 \mathrm{~A}$ and $t=7200 \mathrm{~s})$ at $850^{\circ} \mathrm{C}$ in $\mathrm{LiF}-\mathrm{CaF}_{2}-\mathrm{Li}_{2} \mathrm{O}\left(2\right.$ mass.\% $\left.\mathrm{Li}_{2} \mathrm{O}\right)$.

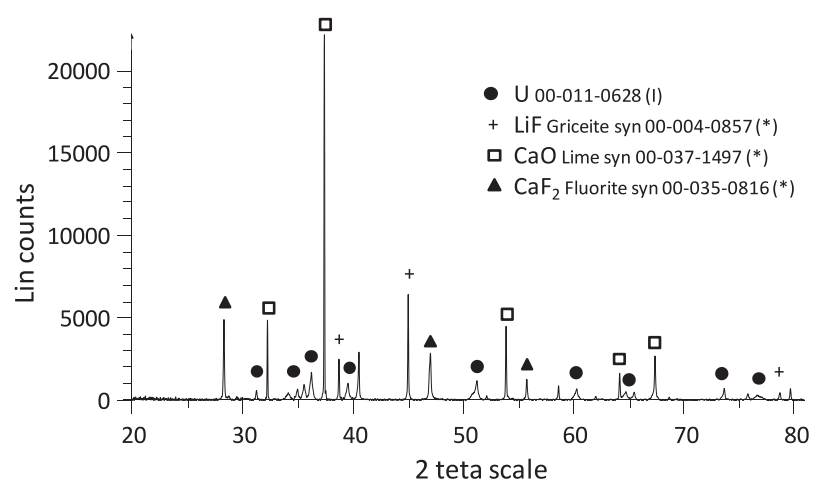

Fig. 8. R-ray spectrum of an electroreduced $\mathrm{UO}_{2}$ pellet $(I=-0.3 \mathrm{~A}$ and $t=7200 \mathrm{~s})$ at $850{ }^{\circ} \mathrm{C}$ in $\mathrm{LiF}-\mathrm{CaF}_{2}-\mathrm{Li}_{2} \mathrm{O}\left(2\right.$ mass.\% $\left.\mathrm{Li}_{2} \mathrm{O}\right)$ after polishing.

and only $\mathrm{CaO}, \mathrm{LiF}, \mathrm{CaF}_{2}$ and $\mathrm{U}$ metal were detected, proving the complete conversion of the pellet into uranium metal. It should be pointed out that no carbide or any mixed $\mathrm{U}-\mathrm{Ca}-\mathrm{Li}-\mathrm{F}$ compound was detected in the sample.

The electrode potential versus time during the galvanostatic electrolysis is plotted in Fig. 9, where a sharp decrease of the potential to $-2.0 \mathrm{~V} / \mathrm{Pt}$ is first observed at the beginning of the electrolysis. Then, the potential remains constant at this value for $1000 \mathrm{~s}$, meaning that there is no sensitive change in the sample conductivity: we assume that uranium oxides still cover the sample surface. Then, an increase of the potential is observed to reach a stable value of $-1.8 \mathrm{~V} / \mathrm{Pt}$. As the reduction process takes place from

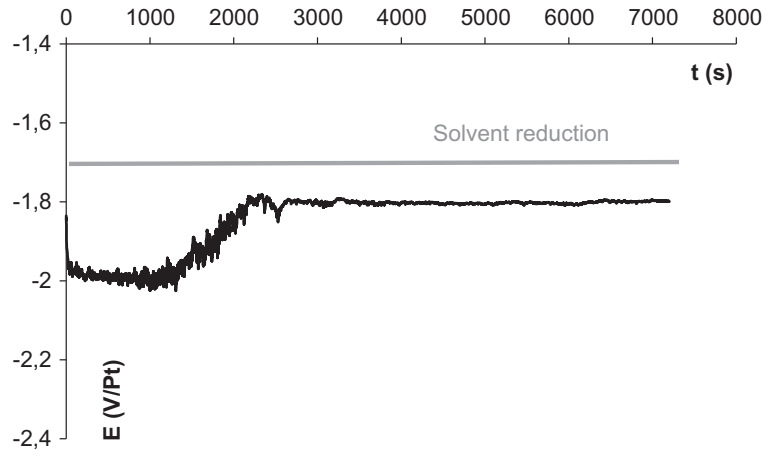

Fig. 9. $\mathrm{UO}_{2}$ pellet potential during galvanostatic electrolysis versus time at $850{ }^{\circ} \mathrm{C}$ in $\mathrm{LiF}-\mathrm{CaF}_{2}-\mathrm{Li}_{2} \mathrm{O}\left(2\right.$ mass.\% $\left.\mathrm{Li}_{2} \mathrm{O}\right): I=-0.3 \mathrm{~A}$ and $t=7200 \mathrm{~s}$. 
the outside of the pellet, $U$ metal is firstly obtained at the sample surface, leading to an increase of its conductivity. When the surface is fully reduced into metallic uranium at $2000 \mathrm{~s}$, a constant potential is achieved.

Finally, it can be noted that the experimental electric charge is four times higher than the required theoretical one. If the solvent reduction potential and the electrode potential during the electrochemical reduction are compared, it appears that $\mathrm{Li}$ metal was formed during the entire process. Combined to the direct electrochemical reduction, it is likely that the indirect reduction of $\mathrm{UO}_{2}$ by metallic Li took place:

$\mathrm{UO}_{2}+4 \mathrm{Li}=\mathrm{U}+2 \mathrm{Li}_{2} \mathrm{O}$

A significant amount of the intensity is then used for Li deposition and yields to a very low current efficiency. To avoid the solvent reduction, the current should be stepwise decreased during the experiment when the potential reaches the $\mathrm{Li}^{+} / \mathrm{Li}$ reduction potential.

\section{Conclusions}

For the first time, fluoride salts have been tested in this work instead of the usual chloride molten salts $\left(\mathrm{CaCl}_{2}\right.$ or $\left.\mathrm{LiCl}\right)$ in order to evaluate their potentialities as electrolytes for the direct electrochemical reduction of $\mathrm{UO}_{2}$. An inert oxygen-evolving gold electrode was used as an anode, instead of the commonly used carbon anode which produces $\mathrm{CO}_{2}$ and leads to the formation of carbides in the reduced cathodic product. The gold anode wasn't attacked as no weight loss was observed (the same gold spiral was used for all runs), validating its use for direct reduction experiments. A complete conversion into metal was achieved at $850^{\circ} \mathrm{C}$ and XRD analysis did not reveal the presence of any carbide phase. Moreover, partially reduced sample indicates the presence of metallic uranium at the grain boundary, showing that the reduction process took place progressively in the pellet starting from the outside. These results call for more investigations on the use of fluoride mixtures as electrolytes for the direct reduction process.

\section{Acknowledgements}

The authors thank B. Deschamps, P. Allegri and E. Brackx from CEA for they analytical contribution.
This work was supported by the European ACSEPT (FP7-CP2007-211267) Program.

\section{References}

[1] P. Souček, R. Malmbeck, E. Mendes, C. Nourry, J.P. Glatz, Recovery of actinides from spent nuclear fuel by pyrochemical reprocessing, in: Proceeding of Global 2009-Paris, September 6-11, 2009

[2] T. Kato, T. Inoue, T. Iwai, Y. Arai, J. Nucl. Mater. 357 (2006) 105-114.

[3] J.J. Laidler, J.E. Battles, W.E. Miller, J.P. Ackerman, E.L. Carls, Prog. Nucl. Energy 31 (1997) 131-140.

[4] Y.S. Hwang, M.S. Jeong, S.W. Park, Prog. Nucl. Energy 49 (2007) 463-472.

[5] T. Usami, T. Kato, M. Kurata, T. Inoue, H.E. Sims, S.A. Beetham, J.A. Jenkins, J. Nucl. Mater. 304 (2002) 50-55.

[6] T. Usami, M. Kurata, T. Inoue, H.E. Sims H, S.A. Beetham, J.A. Jenkins, J. Nucl. Mater. 300 (2002) 15-26.

7] G.Z. Chen, D.J. Fray, T.W. Farthing, Nature 407 (2000) 361-364.

[8] C. Schwandt, D.J. Fray, Electrochim. Acta 51 (2005) 66-76.

[9] T.H. Okabe, I. Park, K.T. Jacob, Y. Waseda, Production of niobium powder by electronically mediated reaction (EMR) using calcium as a reductant, J. Alloys Compd. 288 (1-2) (1999) 200-210.

[10] K. Yasuda, T. Nohira, R. Hagiwara, Y.H. Ogata, Electrochim. Acta 53 (2007) 106110.

[11] M. Kurata, T. Inoue, J. Serp, M. Ougier, J.P. Glatz, J. Nucl. Mater. 328 (2004) 97102.

[12] M. Iizuka, Y. Sakamura, T. Inoue, J. Nucl. Mater. 359 (2006) 102-113.

[13] M. Iizuka, T. Inoue, M. Ougier, J.P. Glatz, J. Nucl. Sci. Technol. 44 (5) (2007) 801813.

[14] V.A. Lebedev, V.I. Sal'nikov, D.A. Rymkevich, Russ. J. Appl. Chem. 809 (2007) 1503-1508.

[15] H. Kawamura, Y. Ito, J. Appl. Electrochem. 30 (2000) 571-574.

[16] Y. Ito, T. Shimada, H. Kawamura, Proc. Electrochem. Soc. 16 (1992) 574-585.

[17] S.M. Jeong, H.S. Shin, S.H. Cho, J.M. Hur, H.S. Lee, Electrochim. Acta 54 (2009) 6335-6340.

[18] L. Massot, L. Cassayre, P. Chamelot, P. Taxil, J. Electroanal. Chem. 60617 (2007) $17-23$.

[19] L. Massot, P. Chamelot, F. Boyer, P. Taxil, Electrochim. Acta 47 (2002) 19491957.

[20] P. Chamelot, P. Taxil, B. Lafage, Electrochim. Acta 39 (1994) 2571-2575.

[21] A.D. Graves, D. Inman, Nature 208 (1965) 481-482.

[22] I. Barin, O. Knacke, O. Kubaschewski, Thermochemical Properties of Inorganic Substances, Springer-Verlag, Berlin, 1977.

[23] R.G. Reddy, S.G. Kumar, Met. Mater. Trans. B 24B (1993) 1031-1035.

[24] K. Yamada, S. Yamanaka, M. Katsura, J. Alloys Compd. 271-273 (1998) 697701.

[25] D.W. Wheeler, S.T. Morris, J. Nucl. Mater. 3851 (2009) 122-125.

[26] O. Bonino, O. Dugne, C. Merlet, E. Gat, P. Holliger, M. Lahaye, J. Nucl. Mater. 294 (2001) 305-314. 